\title{
The role of aid agencies in the media portrayal of children in Za'atari refugee camp
}

\author{
Toby Fricker
}

When the Syrian conflict escalated in early 2012, there was still little sense that this would result in what is now described as the world's biggest humanitarian crisis of our time. ${ }^{1}$ But by mid-2012, thousands of Syrians, half of whom were children, started fleeing their country for safety across borders, including to their southern neighbour, Jordan. ${ }^{2}$ To cope with the rapid influx of people, the Jordanian government opened Za'atari refugee camp in late July 2012, with support from the Jordan Hashemite Charity Organisation, United Nations agencies and other partners. ${ }^{3}$ In the harsh conditions of Jordan's northern desert, Za'atari rapidly became a massive aid operation and at the same time the media face of not only the refugee crisis in Jordan but across the region.

What was apparent, from the early days of the camp, was the large numbers of children and young people fleeing Syria, with more than half of the Za'atari population under eighteen years of age. ${ }^{4}$ For visitors, statistics were unnecessary; there were simply children everywhere. The majority came from the southern Syrian province of Dar'a, where the conflict first erupted. It was from here that children became central to the narrative of the Syrian conflict, when in March 2011 a group of teenagers painted a phrase on their school walls in Dar'a town calling for the fall of the government. ${ }^{5}$ The boys were reportedly arrested, beaten and tortured in prison. ${ }^{6}$ After Friday prayers on 18 March 2011, a protest march took place during which five demonstrators were killed and the conflict in Syria was born. ${ }^{7}$

The hundreds of refugees crossing to Jordan daily turned to thousands by late 2012 and Za'atari grew rapidly in size. Aid agencies found themselves in a race against time to provide shelter, food, schooling and other services for those arriving. ${ }^{8}$ At the same time, journalists and TV crews from across the world became part of the Za'atari landscape. The camp was a major news story and by August 2013, the 120,000 Syrians were living within a melting pot of aid workers, journalists, visiting politicians and celebrities. ${ }^{9}$ Through extensive experience of working with media in Za'atari, news reports from international English-language media and academic literature, this chapter looks at the portrayal of children in media coverage of the camp. 
By analysing how reporting on children's issues evolved over a three-year period and the role of aid agencies in the newsgathering process, this piece of work argues that the relationship between humanitarian organisations and journalists can be mutually beneficial and result in reporting with deeper context and nuance, whilst better protecting children along the way.

There are well-documented concerns about the focus on media work by aid agencies and their close relationship with journalists. Simon Cottle and David Nolan claim that, 'These developments imperil the very ethics and project of global humanitarianism that aid agencies historically have done so much to promote.. Glenda Cooper also questions the editorial integrity of journalists working with aid agencies: 'While journalists - if sometimes imperfectly - work on the principle of impartiality, the aid agency is usually there to get a message across: to raise money, to raise awareness, to change a situation. ${ }^{11}$ Despite this, the collaboration between aid agencies and journalists may serve each other's interests but also produces more informative, accurate and engaging media content for the reader, viewer or listener. With increasing debate and discussion about the rising role of fake news and in a post-truth political environment this could be more important than ever. ${ }^{12}$

This outlook is most likely too positive for some but the case is put forward by focusing on the period from the opening of Zaatari camp in late July 2012 until July 2015, during which two phases of media coverage are identified. The first could be termed a more hard news approach that mirrors the acute emergency phase of aid operations in Za'atari, where children are framed in what could be perceived as a more negative manner. For example, children who vow for revenge in the fight back in Syria and others who play a role in the reported lawlessness of the camp's earlier days. While the second phase of media coverage, from early 2014 until mid2015, reflects a more features led approach with deeper context and nuance to articles, presenting children as more actively and positively involved in camp life. This includes articles about children desperate to continue their education and others who are improving their living conditions by designing small gardens. Reporting that reflects an ongoing childhood and aspirations for the future, despite everything children have been through.

\section{A newsworthy venture}

After opening, Za'atari rapidly became a major global news story, with significant media coverage from the camp focusing on issues related to children and young people. Given that this was, as Sean Healy and Sandrine Tiller note, the most easily accessible camp in the highest profile conflict in the world, it may not be surprising. ${ }^{13}$ But it is important to consider the news values for foreign media coverage, such as those cited by Johan Galtung and Mari Holmboe Ruge, to provide some insight in to the media's decision-making process for coverage from Za'atari. ${ }^{14}$ This helps us to better understand how and why reporting evolved over time and what role aid 
agencies may have had in influencing the discourse used. Galtung and Ruge focus on the process that leads to a story being produced, 'a chain that could have seven or eight steps in it or be much shorter if the newspaper has a correspondent.' ${ }^{15}$ Whether there is a reporter on the ground close to the location of the 'event' is an important consideration. For at the top end of the chain, where editorial decisions are made in capitals far from the news, exacting influence can be more challenging. When a correspondent is present, there are greater opportunities for aid agencies to play a more direct role. In both cases, personal relationships are critical, for journalists not only bring with them the interests of their organisation but also their own experiences in society, which are, as Rukhsana Aslam notes, 'ingrained in their minds from childhood'. The reporter, as an individual, interprets the events they cover and forms the 'first draft of history', which is why the relationship between aid workers and journalists is so important. ${ }^{16}$

Whether a reporter gets to the relevant location in the first place relies on a number of factors. Economic issues, distance, safety and media accreditation all play their part. The economic interests of media outlets are often at the forefront and with foreign news budgets shrinking sustained coverage of humanitarian crises is a challenge. ${ }^{17}$ As John Simpson notes, 'Most newspapers have largely sacked their foreign correspondents, relying instead on one or two staff members, one in, say, the United States and the other perhaps in the Middle East..$^{18}$ Despite this, conflicts, natural disasters and health emergencies are more likely to fit the required narrative of big bangs and negative news to justify the cost of covering the story. ${ }^{19}$ When there is a major 'event' within these crises, as opposed to an ongoing process, this is also more likely to be reported..$^{\circ}$ Add in some elite people, or celebrities, and the probability that it will become news rises further. ${ }^{21}$

In the case of Za'atari, access was not such a pertinent issue. Travelling to Jordan is easy, safe and relatively inexpensive, while at just over an hour from the capital, Amman, the camp is an easy day trip, with a full range of accommodation options on return. Once in Jordan, acquiring media permits to enter the camp was initially straightforward and required not much more than an email and printed acceptance. When this process became more complicated in late 2013, there was a shift in the working relationship between aid agencies and journalists. But there were also a number of layers of access, as the journalist Rana F. Sweis noted:

In order for me to see some of the refugees in the centers and other spaces, I had to organize this through the respective aid agencies. So in some ways the aid agencies were facilitators and in other ways they were the experts on the issues and provided me with information I often needed. ${ }^{22}$

To enter the schools, health clinics and youth centres in the camp, as in any town, you needed permission and aid agencies were primarily managing these services. There was at the least a forced relationship, though journalists were not always 
interested in activities at the centres. In phase one of coverage, Syrian refugees were vital sources for reporters to get first-hand information about the situation inside Syria. Journalists were primarily focused on talking with families who had just fled their country. The Syrian refugee population in Lebanon was very scattered, with no official camps, and those in Turkey and Iraq harder logistically and more expensive to reach. From its outset, the war in Syria has been extremely dangerous to cover. In 2012, Reporters without Borders called Syria a 'Cemetery for News Providers'. In the following years, the conflict became even more complicated and dangerous to cover. Journalists would often request to interview people who had just arrived from Syria, those who could provide stories from across the border just 15 kilometres away. This changed when Zaatari was declared full by the camp management and Syrians arriving in Jordan were sheltered in Azraq camp that opened at the end of April 2014. ${ }^{23}$ Azraq, from its outset, had much stricter regulations for journalists and interviewing families was a much more controlled process.

Events inside Za'atari also met the news values in that, 'The more negative the event in its consequences, the more probable that it will become a news item. ${ }^{24}$ Incidents of unrest, violence and sexual harassment all fed the media agenda. It was an abnormal environment: a camp that grew out of the desert within months and by March 2013 was being referred to as Jordan's fifth largest town. ${ }^{25}$ Regular high profile visitors and elites, from actress Angelina Jolie to the US Secretary of State, John Kerry, also contributed to the regular media coverage, despite the fact that only 15 per cent of the Syrian refugee population lived in Za'atari. It was very challenging to convince journalists to cover stories outside of the camp. There were concerted efforts by a number of aid agencies to do this but with few results, particularly during the earlier days of the camp.

\section{The Za'atari child}

The first phase of media coverage includes the period from the opening of the camp until early 2014. During this timeframe, Zaatari became synonymous through the media, for being a lawless place where children ran riot and harboured thoughts of revenge on their return to Syria. 'We are going to kill them with our knives, just like they killed us', eleven-year-old Ibtisam is cited as saying in one New York Times article titled, 'Syrian Children Offer Glimpse of a Future of Reprisals.' ${ }^{26}$ This early media discourse portrays children in a more aggressive and threatening manner, young people who were not only responsible for playing a role in the instability of the camp but who were looking to fuel the fight back home. 'Young Refugees to Haunt MidEast for Years', reported Mark MacKinnon for Canada's Globe and Mail. ${ }^{27}$ While Catherine Philp's UK Times story led with, 'Children are Groomed for War in Huge Refugee Camp. ${ }^{28}$

The attention-grabbing headlines may not be surprising but within the main body of the articles, the portrayal of children often reflects the pre-existing frames that 
Jaap Van Ginneken notes as being critical to media producers and consumers in their understanding of the world. ${ }^{29}$ Philp writes about meeting a boy playing computer games on the camp's main street. 'Counter Strike, has become the most populous diversion for the thousands of young, restless boys of Zaatari refugee camp. "It teaches us how to fight jihad", nine-year-old Mohammed is quoted as saying. ${ }^{30}$ MacKinnon also uses the computer game analogy:

Counterstrike, which pits terrorists against counterterrorists. Players watch over the barrel of a virtual assault rifle as bullets slash through virtual enemies. Also, because the computers are connected, kids can divide into teams and recreate 'Regime against Rebels.3.

The article goes on to explain how another child is waiting for his chance to join the jihad, following a question to the boy about how the war is going. The link in the articles between violent computer games and the conflict that the children fled is in some ways pertinent. It highlights an example of what Galtung and Ruge call 'cultural proximity' that helps to engage an audience. 'That is, the event-scanner [audience] will pay particular attention to the familiar, to the culturally similar, and the culturally distant will be passed by more easily and not be noticed. ${ }^{32}$ Parents geographically removed from the Syrian crisis can identify with this image being played out in their own homes. But while a European or North American child plays the game for fun, the children in Zaatari prepare themselves for jihad, framing Syrian children within the global terrorism narrative. As David Altheide notes, terrorism has become a dominant frame surrounding many cultural and institutional narratives, which produces a code for the 'fear of the other'. ${ }^{33}$ With media texts a part of our world, this positioning may not be surprising, 'for these texts and images are social phenomena and often part of the debate about society going on in the world. ${ }^{34}$ The language used influences how we talk or think about a subject and as Suzanne Franks has highlighted, public awareness about humanitarian disasters is primarily defined by the media, which is why the discourse used in representing Syrian children is so important. ${ }^{35}$ When Philp's story was read by a Jordanian aid worker in the camp the response was, 'This presents a twisted version of the reality in Za'atari. ${ }^{6}{ }^{6} \mathrm{He}$ was particularly surprised by the jihad reference stating that it was quite normal for children to play the game for fun, as opposed to the article's more sinister insinuation. This framing is maybe predictable, as Jean Seaton notes, 'stories news-makers construct are often shaped by a limited range of established narratives into which diverse and real events are fitted'. ${ }^{37}$ In some articles, quotes from aid workers were used to help explain why children behaved in a more aggressive manner. 'Such profound stress can be mind-altering, especially for young brains, which switch off simply to survive ... They can't determine risk anymore and when they get angry they have no ability to control these impulses', a child protection officer is quoted as saying. ${ }^{8}{ }^{8}$ While this provides valuable context, it could be argued that the overall framing of the article 
around children's determination to exact revenge already presented children as complicit in the violence. On some occasions, the concerns raised by humanitarian organisations played in to this narrative. For example, one aid worker is quoted as saying, 'I'm afraid of the kids here. ${ }^{39}$

The Syrian population crossing in to Jordan presented a different image of children affected by humanitarian crises. The 'Live Aid Legacy' visual, of 'starving children with flies around their eyes', wouldn't fit the narrative, nor was the reality, for Syrian children in Za'atari..$^{+0}$ They were not poverty-stricken or malnourished but were from the working- and middle-class communities of towns and villages across Syria. They were living a childhood like any other children, most were attending school in a country that had a 97 per cent enrolment rate before the conflict. ${ }^{41}$ But they were now deeply traumatised from their experiences of conflict and displacement. This is an important consideration when it comes to the aid agency response and media discourse from Za'atari. Education and child protection issues came to the forefront, two sectors that are often not prioritised, particularly when it comes to funding. For example, prior to the Syrian crisis education in emergencies received on average just 2 per cent of humanitarian aid funds. ${ }^{42}$ In this new environment, aid agencies focused on raising awareness about the education and child protection issues affecting Syrian children. The 'No Lost Generation' initiative was one example of this work. ${ }^{43}$ The campaign included multiple partners and was designed to highlight the critical needs of getting Syrian children back to school, as well as 'to help them heal from the horrors of war and displacement and to better engage young people in the issues affecting them.' ${ }^{4}$ The initiative was to act as an early warning message about the long-term impact of a whole generation of children growing up through conflict, at the same time there was a clear fundraising goal to support the two sectors of often underfunded humanitarian assistance. The language used in the 'No Lost Generation' initiative is one of urgency. 'An entire generation of Syrian children and youth are living through conflict and displacement. They are on the verge of being a lost generation.'45 The warnings balanced with a sense of hope, 'But against all odds, children and youth are not giving up on their dreams and aspirations', and a call for support, 'We all must do more to provide them with opportunities to heal, to learn and to thrive again'. The discourse was used in varying degrees across a number of media reports. 'A Lost Generation: Young Syrian Refugees Struggle to Survive', led a New York Times article by Jodi Rudoren, the story reflecting some of the key concerns raised by aid agencies about the futures of Syrian children.

These children, the next lost generation, make up a particularly troubling category of collateral damage from Syria's chaotic conflict, which has left 70,000 people dead. There is Ahmad Ojan, fourteen, who wanted to be a teacher, but now spends his days peddling tea in Jordan's sprawling Za'atari refugee camp. And there is Marwa Hutaba, fifteen, who still hopes to be a pharmacist, but is increasingly worried she might be married off to a wealthy foreigner - like the fourteen-year-old who disappeared from school after 'getting engaged one day and married the next. ${ }^{\prime}{ }^{6}$ 
Freelance journalist Stephanie Parker, who reported for the New York Times, stated that, 'I'm very aware of the No Lost Generation initiative. In the series of stories that I wrote revolving around refugees I used the spirit of the program and the importance of it without directly referencing the campaign'. ${ }^{47}$ While Parker knew about the initiative, many other journalists did not but the essence of a 'Lost Generation' of Syrian children was picked up in many articles. The involvement of multiple aid agencies in the initiative, at a headquarters, regional and country level, helped create a common discourse when talking about education and child protection issues with the media. 'Inside a Refugee Camp with Syria's "Lost Generation"' led a NBC News story. ${ }^{48}$ While the headline implied that it was too late for the children, the article reflected the essence of the issue. 'Gassem and Jalal have not stopped thinking about the future. Even though he is too intimidated to attend school in the crowded camp full of strangers, Gassem dreams of one day becoming a doctor.' The No Lost Generation initiative played a role in framing the education and child protection issues in Za'atari within the media. This is not to say that the news selection process was necessarily influenced, for as Silvio Waisboard notes, there are so many determining factors along the media chain. ${ }^{49}$ But the common discourse helped aid agencies to present one voice around the relevant issues when working with media.

\section{The shifting media narrative and evolving conditions on the ground}

As time progressed, it was clear that the conflict in Syria was not going to be resolved soon. Life in Za'atari became more routine and stable, with an increasing sense of semi-permanence in the camp. By early 2014, a shift in the nature of media coverage can be identified, with articles that looked more at the resolve of children and their active involvement in camp life, as opposed to direct association with the conflict back home or violence within Za'atari itself. The hard news giving way to an increasingly features-led approach, for example 'The Secret Gardens of Syria's Refugee Camps' in which children and their parents are involved in a gardening project organised by the NGO, Save the Children, to 'start building just a bit of hope and happiness.'.5 Or the children who enrol in taekwondo classes and are featured in a documentary and Buzzfeed article, 'a surprisingly uplifting story in the midst of all this tragedy'.1 The case of then fourteen-year-old Muzoon is another example. 'Syrian Teen is Called "the Malala of Za'atari"', ran a CNN edition headline.53 'We can help and improve our nation with education', Muzoon is quoted as saying. While there is recognition of the desperate situation that many Syrian children face, the story focuses on the childhood dreams of one young girl. 'Days go by, and an end to the Syrian crisis does not seem near, but [Muzoon], who dreams of someday becoming a journalist, is already thinking of better days for her country's future', reports Alvarado. The work behind this story provides an interesting example of the intersection between aid agencies and journalists. In the summer of 2013, Muzoon was part of a team of girls who went from home to home trying to convince children and their parents to enrol 
them for school. ${ }^{54}$ An articulate and inspiring girl, Muzoon played a key role in advocating for children to continue their education in the camp. For media she was an obvious choice and Muzoon spoke to a number of news outlets but it was following the visit of global education advocate, Malala Yousafzai, with whom she spent a day in the camp in February 2014 that journalists would specifically ask to talk with her (see figure 8.1). The focus on Muzoon by the media meant she played a critical role in changing the discourse around young people's issues. But the relationship with the media had to be carefully managed by aid agencies. Resentment within the community, a perception of preferential treatment and a lack of opportunity for other girls were some of the issues that had to be addressed.

Another example of the shift in media portrayal of children is an audio photo essay, 'Through Teenagers' Eyes: Unique Snapshots of Syrian Refugee Life', featured by BBC Online. .5 The content focused on a project run by the charity, Save the Children, that included the work of Syrian teenagers in photographing their lives in Za'atari. The $\mathrm{BBC}$ on this occasion published prepackaged content. 'I want to be a famous photojournalist and travel the world', says Khaled. . $^{6}$ 'The children struck me as being very optimistic for their situation', adds photographer Michael Christopher Brown, who worked with the children. The involvement of an internationally renowned photographer may well have helped in the placement but the

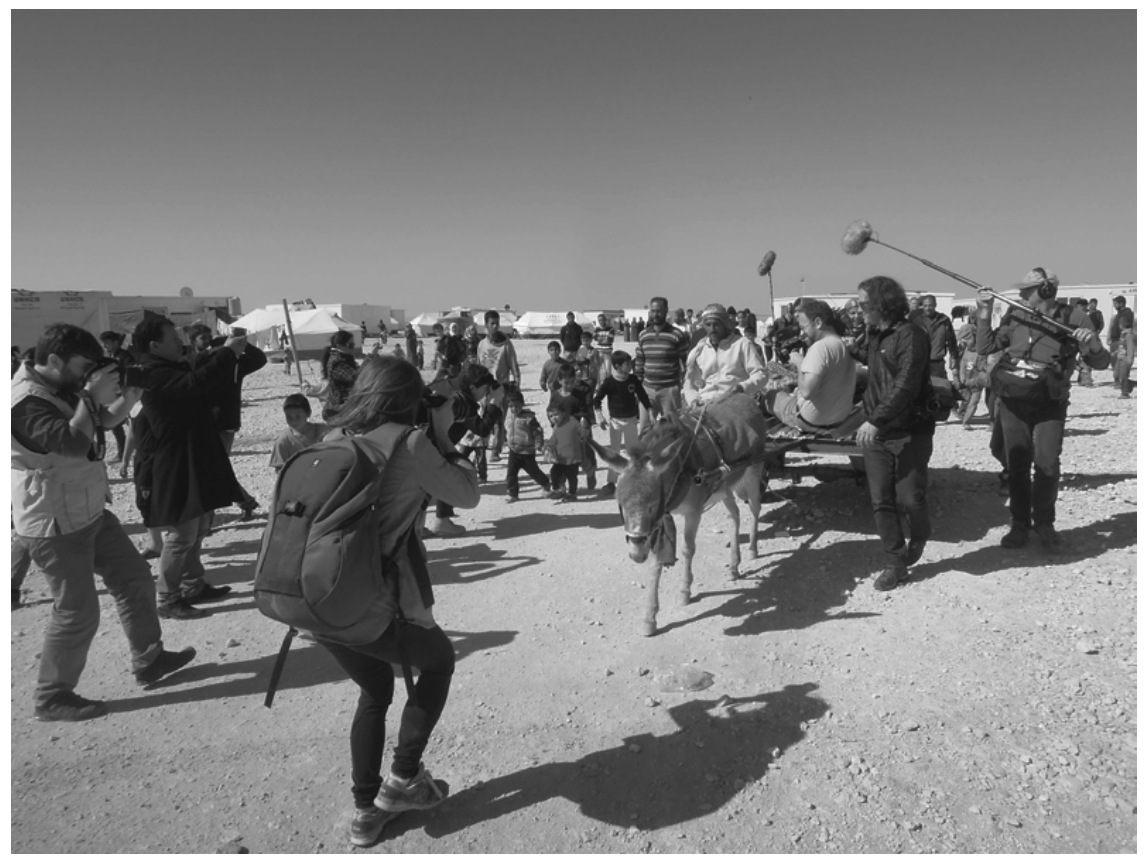

Figure 8.1 Malala Yousafzai at the camp 
voices presented here are a far cry from the sentiment of the children who expressed their desire for jihad in the earlier articles reviewed. While it can be expected that content produced by an aid agency about one of its projects would focus more on the positives, it was still exposed to the news selection process, as part of the BBC's coverage.

It is important at this point to revisit the issue of access, as a factor in the evolving media coverage of children's issues in Za'atari. As mentioned earlier, media permits to access the camp were granted relatively easily during the first phase of reporting and journalists were freer to come and go. The conditions on the ground meant that reporters could take more time, or the amount allocated by their organisation, to identify their stories and the children to interview. But this changed in late 2013 and the earlier reporting, perceived as more sensationalist, was a contributing factor. The process for acquiring media permits for Za'atari became more stringent and, when granted access, journalists were only allowed two days to report from the camp before having to apply again. This played a role in changing the working relationship between journalists and aid agencies on the ground. The portrayal of children in Za'atari during phase one of coverage, from potential jihadists to the camp's number one troublemakers, had a direct impact on families living there. As Linda Polman highlights, 'Most refugee camps have TVs that can pick up CNN, so refugees see how "we" portray victims. ${ }^{57}$ While Za'atari residents were not watching $\mathrm{CNN}$, they were viewing other satellite channels in 2013. There was also access to the internet through phones and many residents were in regular contact with relatives both inside Syria and further afield. The high profile presence of media in the camp from the outset had been tolerated by most people in the camp. While some were not willing to talk with journalists, or be photographed, for fear of repercussions on family members back home and because they were expecting to return to Syria, others wanted to tell the world their stories in the hope of more outside support. But as more reporters came to Za'atari and the situation inside Syria got worse, residents became less tolerant of what they perceived as a negative portrayal of Syrians in the camp, including children. Coverage of the so-called pleasure marriage story became particularly problematic.

The story of pleasure marriages was based on Syrian women and girls who were being married off to older men, the majority of whom were reported to have come from Gulf countries. These marriages would then be annulled within a couple of months or weeks, as the men left, so in effect a form of prostitution. 'In a Jordan Camp, Outsiders Seek Syrian Brides', reported the Washington Post. ${ }^{58}$ While the Daily Telegraph highlighted how Syrian girls were being sold into 'forced marriages. 59 'The "dowry", which in Muslim society is traditionally paid by the groom as a guarantee of the bride's security, has become a payment for sex. And the "marriage", is an affair that lasts only a few days or even hours', the article explained. This pleasure marriage narrative was predominant in the first phase of media coverage and was a very sensitive subject in the camp. An Agence France Presse article featured a father 
who explained that he had no choice but to marry off his teenage daughter to a fortyyear-old Saudi man. ${ }^{60}$ The report also highlighted how a group of activists in the camp were trying to stop the marriages. "We launched a revolution to win back our dignity," Naimi said. "We are not going to surrender it for a dowry”. These emotions would soon have an impact on the work of journalists in the camp. Aid agencies spoke about their concerns of the reported pleasure marriage practice but had few hard facts to add to the story. 'We have seen no evidence of prostitution in the camp, but we have heard rumors of it', the head of the United Nations Refugee Agency (UNHCR) in Jordan, Andrew Harper, was cited as saying in an Associated Press article. ${ }^{61}$ 'Given the vulnerability of women, the camp's growing population and the lack of resources, I'm not surprised that some may opt for such actions', he added. In a number of quotes on the issue, Harper framed the problem around a need for more financial support for aid agencies, so that families could be better assisted and as a result were not driven to such desperate measures. When journalists reported on the story, they would often source the affected girls in the camp themselves. One of the first locations to visit was the wedding dress shop on Za'atari's market street. A steady stream of reporters went to take photographs and conduct interviews. But there was growing frustration amongst residents about the way media were portraying Syrian girls. When a TV crew from Al-Arabiya arrived on the camp's market road in October 2013, rumours spread that they were focusing on a pleasure marriage story, and they were subsequently attacked and had to be escorted to safety by Jordanian police. ${ }^{62}$

In late 2013, the Jordanian authorities reduced the permitted reporting time in Za'atari to two days per visit and journalists were required to leave the camp by 3 p.m. each day. With less time, this meant an increased reliance on aid agencies to access stories and families in the camp. But this development also came at a time when aid agencies had to be more careful than ever when accompanying journalists around the camp. It could be problematic to be associated with media who were perceived to be contributing to the negative image of Syrian girls and residents of the camp as a whole, or media outlets whose governments took a particular political stance. For example, some families in Za'atari would not talk with Chinese or Russian media, given their countries' backing of the Syrian government. While aid workers were building stronger relationships with people in Za'atari and given their long-term presence on the ground, they did not want to jeopardise this. As Kimberly Abbot notes, 'The lives of staff members, especially nationals, can be endangered, if reporters they accompany are associated with the "wrong side" ' or are reporting in what is seen as a more exploitative manner. ${ }^{63}$ But media embedding with aid agencies that would normally be more prominent in the first acute phase of an emergency, became more common and critical, as reporters were time-restricted. Aid agencies could provide journalists with quick access to stories and an overview of the problems and issues. Working with journalists in covering sensitive issues, such as the pleasure marriage story, was 
important in other ways. Despite not being able to add specific facts or information about the pleasure marriage phenomenon, supporting reporters who would cover the story anyhow could help to better protect and support children and families interviewed. A specific handbook for journalists was produced with guidance on 'Reporting on Gender-Based Violence in the Syrian Crisis', which highlights how 'child marriage is not always perceived as a "real" form of gender-based violence, so journalists can be unscrupulous in sharing details, including pictures of young brides. ${ }^{64}$ By being involved in the newsgathering process, child protection workers can help to create a more protective environment. For example, framing questions in a more sensitive way and through providing follow-up support to the child after their interview. Freelance reporter, Stephanie Parker, noted that:

Agencies did have a big impact on how I reported because organisations like UNICEF acted as a gatekeeper, protector, or armed guard of the children if you will. This protection type attitude made me feel comfortable and at ease about how the children were being treated and grateful that they wanted to speak to me about their family life and circumstance. ${ }^{65}$

\section{From pleasure to early marriage}

The coverage of the so-called pleasure and early marriage issue provides a deeper insight into the evolving narrative between phase one and two of reporting from the camp. The pleasure marriage story became newsworthy in the earlier days of Za'atari, as the issue fitted well into the news frame. It was an event, whereby a girl is married and then the so-called marriage is relatively quickly annulled. This is important, as Jake Lynch and Johan Galtung note, the rhythm of news is punctual, based on events not processes that take more time to evolve and reveal where they are headed. ${ }^{66}$ The pleasure marriage story also demands attention of readers because it 'crashes through routine order. ${ }^{67}$ Young girls from a religious conservative background are sold off to rich men from the Gulf. For international readers, this is a shocking consequence of the refugee crisis. The media spotlight, in the pursuit of readers, ratings and revenue, is, as Cottle and Nolan note, drawn selectively to images of distress rather than issues of structural disadvantage, in which early marriage would more clearly fit. ${ }^{68}$ The portrayal of Syrian girls, as being exploited through the pleasure marriage narrative, was a factor that changed the working conditions for journalists on the ground and, as highlighted, potentially played a role in complicating media access to Za'atari. By early 2014, media coverage of the issue evolved to look in more depth at the practice of early marriage amongst the Syrian refugee population. While both pleasure and early marriage are classified as gender-based violence and detrimental to the futures and health of the girls involved, the nuances between the two are important. ${ }^{69}$ They are fundamentally different issues that require different types of responses. As Mukkaram Odeh notes: 
The crisis complicated this problem [early marriage] even more because of the lack of safety and stability. It increased fears regarding economic challenges and harassment, and many refugee families believe that their daughters will be safer if they are married. ${ }^{70}$

While there were financial considerations, there was a sense amongst some families that it was in the best interest of their girls to marry younger, and in the majority of cases to men within their own community.1 The pleasure marriage story, however, was driven by a narrative of exploitation. When new statistics on the extent of early marriage amongst Syrian girls were verified in mid-2014 it provided an opportunity for aid agencies to present a more in-depth picture. The release of two new reports by UNICEF and Save the Children were timed to coincide with the 2014 'Girl Summit', hosted by the UK government and UNICEF in London. The gathering aimed to push for 'concrete commitments to end child, early and forced marriage and female genital mutilation for girls everywhere..$^{22}$ The UNICEF report, 'A Study on Early Marriage in Jordan, 2014', showed the rate of child marriages amongst Syrian refugees in the country increased from 18 per cent of total marriages in 2012, to 32 per cent in 2014, while 'Too Young to Wed' focused more on case studies and stories of girls who had married early. ${ }^{73}$ The new statistics and information in the reports, including quotes from affected girls, were picked up by a range of media. The Guardian highlighted the increasing numbers of girls marrying early and the subsequent impact, 'Child marriage among Syrian refugees in Jordan has more than doubled since the start of the conflict, leaving girls vulnerable to health problems, domestic abuse and poverty, the UN has warned'. The article went on to identify the factors responsible for children marrying early, as well as further depth into the long-term impact. 'They [girls] also have more limited economic opportunities due to loss of schooling and can get trapped in a vicious cycle of poverty', the UNICEF Jordan Representative was quoted as saying. ${ }^{74}$ 'Child marriages double among Syria refugees in Jordan', reported Agence France Presse, while Buzzfeed used photos of drawings produced by Syrian girls in Za'atari to raise awareness about the dangers of child marriage. ${ }^{75}$ The article presented a more creative and visual way to tell the story. The communications products to accompany the new reports were produced to target media outlets and conform to the known dispositions of news organisations. ${ }^{76}$ A process that Natalie Fenton refers to as " "news cloning" that mimics, or indeed matches, the requirements of mainstream news agendas', but does not mean that aid agencies 'have managed to change news agendas and challenge normative conceptions of news criteria. ${ }^{77}$ Cottle and Nolan believe that by working in this way aid agencies 'practically detract from their principal remit of humanitarian provision and symbolically fragment the historically founded ethic of universal humanitarianism. ${ }^{78}$ However, in the case of the early marriage reports and related communications products, it renewed focus and presented an opportunity to advocate for more support to tackle the issue, whilst providing additional context and reporting in a more dignified way for the girls and families affected. This is particularly important, as media attention of early marriage 
had mixed consequences. 'Syrian girls and their families reported feeling that the media contributed to a negative perception of Syrian women and girls, and sometimes reacted by increasing isolation and control over young women. ${ }^{\text {'9 }}$

There was a spike in coverage of the early marriage story around the 'Girl Summit' and the reports also led to follow-up coverage from journalists in subsequent months, for example an article by the New York Times, 'In Jordan, Ever Younger Syrian Brides', that looked in depth at the issue. 'The girl, Rahaf Yousef, is 13. Speaking wistfully of her days at school, she declared herself throughout the day to be "indifferent" to the marriage she says will keep her from finishing her education. But no one seemed to be listening.' The article went on to include some of the ongoing efforts to tackle the rising trend:

Aid agencies and organizations are alarmed enough by the increase in early marriages that they have been conducting awareness campaigns. 'You'll be surprised at the lack of knowledge among the community about the devastating health consequences of early marriage,' said Fasel Shammout, a psychologist who has done training for the refugees. 'By the time they reach us, they are in a dire strait - legally, mentally, physically.'.

While the pleasure marriage story was important to cover and may have been a more compelling, simplistic and attention-grabbing narrative, as with the children awaiting their chance to join the jihad, it was far from the full picture.

\section{Conclusion}

The international media narrative covering children in Zaatari camp evolved as time progressed, from one where Syrian children were portrayed as more aggressive and threatening, to a representation that focused more on their resolve and aspirations. The potential influence of aid agencies on this discourse is one of a number of factors to consider, given that many mechanisms intervene to shape the news. ${ }^{81}$ The shift in the discourse reflected life in the camp, as the days became more stable and routine, while the aid operation evolved from an acute emergency operation into a more systematic response. But the loss of trust between the Za'atari population and journalists, as a result of what was perceived as negative media coverage, particularly around the pleasure marriage issue, led to tougher working conditions for reporters. There were direct attacks against journalists and access became harder when the media accreditation process was made more stringent, including a reduction in the time allowed to report from the camp. With less flexibility, there was more of a reliance on aid agencies to source people and stories and as a result a greater role in the newsgathering process.

The Syrian refugee crisis presented a new image of children and young people fleeing war. Working- and middle-class populations forced to flee their houses and apartments for the relative safety of what became the largest refugee camp across the region. While living conditions were tough, it was the loss of education and ongoing psychological recovery from exposure to conflict and displacement that would have 
the most immediate and mid- to long-term impact on children. Initiatives such as 'No Lost Generation' were designed to raise awareness and more funds for these traditionally underfunded sectors of humanitarian work. The discourse used in the campaign was meant to appeal to media and to present the challenges but also the hope and aspirations of Syrian children affected. The nuance of the language arguably in some cases played in to the more negative outlook for Syrian children but the essence of supporting a generation of children to regain their childhood helped to frame the education and protection issues at the forefront of the response. As time went on, media articles in phase two of coverage had an increasingly features-led approach and looked more at children's involvement in camp life and what it meant for their lives. This was in contrast to earlier reporting, where Syrian children were framed within narratives that emerged as part of the so-called 'War on Terror. ${ }^{{ }^{82}}$

This chapter argues that aid agencies can help to provide the extra context required for more sophisticated coverage of issues affecting children during humanitarian crises. This is seen more clearly in the later media reports from Zaatari, as the evolving pleasure to early marriage story highlights. As Abbott notes, NGO and media partnerships are a reality and can lead to stronger foreign news reporting that better serves audiences in our interconnected world. ${ }^{8_{3}}$ In today's society, where the fear of the other is often reflected in media narratives, I would argue that aid agencies have an even more critical role to play, or even a moral obligation, to amplify the voices of children affected, so that they are not drowned out. ${ }^{84}$ The media presents an important opportunity to advocate for the rights of the children affected, to contribute to public education and to support fundraising efforts. While aid agencies have clear goals and aims, the information provided should add to and be a natural part of the story. When aid workers are part of the news process they can also help to better protect children and encourage more ethical reporting on sensitive and traumatic subjects. The media portrayal of Syrian children in Za'atari is so critical because the language used provides us with not just a mode of interaction but also with a capacity for representation. ${ }^{85}$ As the Syrian refugee crisis subsequently spread to Europe, it was in turn followed by a narrative of fear and negativity that often failed to take into account the impact of the situation on children. The effects of this discourse - similar to those prominent in the early days of the Zaatari camp - are now being felt across the world.

\section{Notes}

1 BBC, 'Syria Conflict: "Biggest humanitarian crisis since 1945” - Gordon Brown' (4 February 2016), www.bbc.com/news/world-middle-east-35489063. Accessed 7 June 2016.

2 UNICEF, Shattered Lives: Challenges and Priorities for Syrian Children and Women in Jordan (Jordan: UNICEF, 2013), www.unicef.org/mena/MENA-Shattered_Lives_June11.pdf. Accessed 9 May 2016.

3 S. Wilkes, 'Jordan Opens New Camp for Syrian Refugees Amid Funding Gaps', UNHCR (30 July 2012), http://bit.ly/2b7nnqT. Accessed 21 May 2016. 
4 UNICEF, Shattered Lives.

5 F. Keane, 'Syria: The Boys Who Helped Spark a Revolution', BBC (13 April 2013), http://bbc. in/2bGPPwq. Accessed 25 May 2016.

6 J. Bowen, The Arab Uprisings: The People Want the Fall of the Regime (London: Simon \& Schuster, 2012).

7 Bowen, The Arab Uprisings.

8 The reference to aid agencies in this chapter refers to United Nations agencies and local and international non-governmental organisations (NGOs) working in Za'atari refugee camp.

9 UNICEF, Shattered Lives.

10 S. Cottle and D. Nolan, 'Global Humanitarianism and the Changing Aid-Media Field', Journalism Studies, 8:6 (2007), p. 862.

11 G. Cooper, 'When Lines between NGO and News Organization Blur', NiemanLab (21 December 2009), http://bit.ly/1DpvRKL. Accessed 11 December 2015.

12 'Post-Truth Politics: Art of the Lie,'Economist (10 September 2016), http://econ.st/2bVXLHU. Accessed 20 October 2016.

13 S. Healy and S. Tiller, 'A Review of the Humanitarian Response to the Syrian Refugee Crisis in Jordan 2012-13, MSF (October 2013), www.msf.org.uk/sites/uk/files/jordan_case_study_ final_external_o.pdf. Accessed 25 May 2016.

14 J. Galtung and M. H. Ruge, 'The Structure of Foreign News', Journal of Peace Research, 2:1 (1965), pp. 64-91.

15 Galtung and Ruge, 'The Structure of Foreign News', p. 65.

16 R. Aslam, 'Peace Journalism: A Paradigm Shift in Traditional Media Approach', Pacific Journalism Review, 17:1 (May 2011), pp. 119-39, https://pjreview.aut.ac.nz/articles/peacejournalism-paradigm-shift-traditional-media-approach-476. Accessed 1 May 2016.

17 J. Curran, Media and Power (London and New York: Routledge, 2002).

18 J. Simpson, We Chose to Speak of War and Strife: The World of the Foreign Correspondent (London: Bloomsbury, 2016).

19 J. Lynch and A. McGoldrick, Peace Journalism (Stroud: Hawthorn Press, 2005).

20 J. Lynch and J. Galtung, Reporting Conflict: New Directions in Peace Journalism (Brisbane: University of Queensland Press, 2010).

21 Galtung and Ruge, 'The Structure of Foreign News'.

22 R. Sweis, Interview with the author, 15 June 2016.

23 E. Oddone, 'Azraq Refugee Camp Officially Opened', The Jordan Times (30 April 2014), http://bit.ly/28T4a6F. Accessed 10 May 2016.

24 Galtung and Ruge, 'The Structure of Foreign News'.

25 N. Bulos, 'Jordan Feeling the Strain of Syrian Refugee Crisis', Los Angeles Times (22 March 2013), http://lat.ms/2hftvid. Accessed 18 June 2016.

26 D. Kirkpatrick, 'Syrian Children Offer a Glimpse of a Future of Reprisals', New York Times (3 September 2012), http://nyti.ms/2h8HBBg. Accessed 2 April 2016.

27 M. MacKinnon, 'Why Young Syrian Refugees will Haunt the Mideast for Decades to Come', The Globe and Mail (14 September 2013), http://bit.ly/1k8a5Z2. Accessed 13 May 2016.

28 C. Philp, 'Children are Groomed for War in Huge Refugee Camp', The Times (3o December 2013), www.thetimes.co.uk/article/children-are-groomed-for-war-in-huge-refugee-camp-cn29 tjm97z5. Accessed 10 May 2016.

29 J. Van Ginneken, Understanding Global News: A Critical Introduction (London, Thousand Oaks and New Delhi: Sage, 1996).

30 Philp, 'Children are Groomed for War in Huge Refugee Camp'.

31 MacKinnon, 'Why Young Syrian Refugees will Haunt the Mideast for Decades to Come'. 
32 Galtung and Ruge, 'The Structure of Foreign News', p. 67.

33 P. Altheide, Terror Post $9 / 11$ and the Media (New York: Peter Lang, 2009).

34 J. Stokes, How to do Media and Cultural Studies: Analysing Media and Cultural Texts (London, Thousand Oaks and New Dehli: Sage, 2003).

35 S. Bazzi, Arab News and Conflict: A Multidisciplinary Discourse Study (Amsterdam and Philadelphia: John Benjamins Publishing Company, 2009); S. Franks, Reporting Disasters: Famine, Aid, Politics and the Media (London: Hurst, 2013).

36 Discussion with Abdul Majeed, UNICEF Jordan staff member in Za'atari refugee camp.

37 J. Seaton, Carnage and the Media: The Making and Breaking of News About Violence (London: Penguin, 2005).

38 Philp, 'Children are Groomed for War in Huge Refugee Camp'.

39 MacKinnon, 'Why Young Syrian Refugees will Haunt the Mideast for Decades to Come'.

40 Voluntary Services Overseas, The Live Aid Legacy: The Developing World through British Eyes A Research Report (London: VSO, 2001).

41 UNICEF, Syria Crisis: Education Interrupted: Global Action to Rescue the Schooling of a Generation (UNICEF MENA, 2013), http://uni.cf/2iAQ94z. Accessed 22 May 2016.

42 S. Nicolai and S. Hine, 'Investment for Education in Emergencies: A Review of Evidence', Overseas Development Institute (February 2015), http://bit.ly/2bsBRg2. Accessed 2 April 2016.

43 See http://nolostgeneration.org/partners. Accessed 18 June 2016.

44 See http://nolostgeneration.org/partners. Accessed 18 June 2016. The 'No Lost Generation' initiative includes multiple partners working on the Syrian and Iraqi crises across the region including, 'United Nations agencies and international and local NGOs, as well as governments, international donors, private sector and the young people themselves who are so affected by the crises in Syria and Iraq'

45 See http://nolostgeneration.org/partners. Accessed 18 June 2016.

46 J. Rudoren, 'Calm Boss Overseeing a Refugee Camp's Chaos', New York Times (24 May 2013), http:nyti.ms/2btYNNV. Accessed 26 February 2016.

47 S. Parker, Interview with the author, 29 June 2016.

48 T. Connor, 'Inside a Refugee Camp with Syria's "Lost Generation"', NBC News (26 August 2013), http://nbcnews.to/2hdLAN5. Accessed 2 March 2016.

49 S. Waisboard, 'Can NGOs Change the News?' International Journal of Communication, 5 (2011), pp. 142-65, http://ijoc.org/index.php/ijoc/article/view/787/515. Accessed 11 April 2016.

50 J. Elgot, 'The Secret Gardens of Syria's Refugee Camps', Huffington Post (29 October 2014), http://huff.to/1toj7Vj. Accessed 25 May 2016.

51 A. Vingiano, 'Syrian Children Master Taekwondo at the Za'atari Refugee Camp', Buzzfeed (2 July 2014), http://bzfd.it/2glblHi. Accessed 13 June 2016.

52 Mazoun is the spelling that she uses in English for her name, in the original report the journalist spells the name, Mizune.

53 A. Alvarado, 'Syrian Teen is Called the Malala of Za'atari', CNN International (18 April 2014), http://cnn.it/RrgrWv. Accessed 5 June 2016. Malala Yousafzai the Pakistani schoolgirl who was shot on her way to school in 2009 and was awarded the Nobel Peace Prize five years later for her work in campaigning for girls' education.

54 T. Fricker, 'Students Promote Learning in Za'atari Camp, Jordan', UNICEF (12 September 2013), www.unicef.org/infobycountry/jordan_70365.html. Accessed 25 May 2016.

55 'Through Teenagers' Eyes: Unique Snapshots of Syrian Refugee Life', BBC (13 November 2014), www.bbc.co.uk/news/world-middle-east-29724306. Accessed 22 May 2016.

56 All children's names were changed on the original photo essay to protect identities. 
57 L. Polman, War Games: The Story of Aid and War in Modern Times (London: Penguin, 2010).

58 T. Luck, 'In a Jordan Camp, Outsiders Seek Syrian Brides', Washington Post (23 November 2012), http://wapo.st/2bW5bk8. Accessed 21 August 2016.

59 R. Sherlock and C. Malouf, 'Syrian Girls “Sold” into Forced Marriages', Daily Telegraph (23 January 2013), http:/ / bit.ly/18XBpDT. Accessed 12 March 2016.

60 K. Taha, 'Early, Forced Marriages Haunt Jordan's Syrian Refugees', AFP (12 June 2013), http:// bit.ly/2gRRcte. Accessed 13 March 2016.

61 J. Halaby, 'Desperate, Some Fleeing Syria Turn to Prostitution', Associated Press (8 March 2013), http://yhoo.it/2bvi2ct. Accessed 25 May 2016.

62 Freedom House, 'Jordan' (2014), https://freedomhouse.org/report/freedom-press/2014/ jordan. Accessed 25 May 2016.

63 K. Abbot, 'Working Together, NGOs and Journalists Can Create Stronger International Reporting', NiemanLab (9 November 2009), http://bit.ly/1J7MVt2. Accessed 20 July 2016.

64 United Nations Population Fund, Reporting on Gender-Based Violence in the Syria Crisis: A Journalists Handbook (UNFPA, 2014), www.unfpa.org/sites/default/files/resource-pdf/ UNFPA\%20Journalsits\%27s\%20Handbook\%20Small\%5B6\%5D.pdf.

65 S. Parker, interview with the author, 29 June 2016.

66 Lynch and Galtung, Reporting Conflict, p. 18.

67 Seaton, Carnage and the Media.

68 S. Cottle and D. Nolan, 'How the Media's Codes and Rules Influence the Ways NGOs Work', NiemanLab (16 November 2009), http://bit/ly/1FzwEsR. Accessed 3 March 2016.

69 United Nations Population Fund, Reporting on Gender-Based Violence in the Syria Crisis.

70 M. Odeh, cited in B. Al-Khatib and K. Lenner, Alternative Voices on the Syrian Refugee Crisis in Jordan: An Interview Collection (Rosa Luxemburg Stiftung Regional Office Palestine, 2015).

71 UNICEF, A Study on Early Marriage in Jordan 2014 (Jordan: UNICEF, 2014), www.unicef.org/ mena/UNICEFJordan_EarlyMarriageStudy2014(1).pdf. Accessed 25 May 2016.

72 See www.girlsummit2014.org/Commitment/Show. Accessed 3 March 2016.

73 UNICEF, A Study on Early Marriage; Save the Children, 'Too Young to Wed: The Growing Problem of Child Marriage among Syrian Girls in Jordan', Save the Children (2014), http://bit. ly/1FXQIX 3 . Accessed 12 January 2016.

74 M. Anderson, 'Child Marriage Soars among Syrian Refugees in Jordan', Guardian (16 July 2014), http:// bit.ly/1rhUng1. Accessed 12 June 2016.

75 R. James, '21 Powerful Images of Forced Marriage Drawn by Syrian Refugees in Jordan', Buzzfeed (17 July 2014), www.buzzfeed.com/richardhjames/powerful-images-of-forcedmarriage-drawn-by-syrian-ref\#.okzMzwo7K. Accessed 25 May 2016.

76 Cottle and Nolan, 'How the Media's Codes and Rules Influence the Ways NGOs Work'.

77 N. Fenton, 'Has the Internet Changed How NGOs Work with Established Media? Not Enough', NiemanLab (23 November 2009), http://bit.ly/10CCrMB. Accessed 25 May 2016.

78 Cottle and Nolan, 'Global Humanitarianism and the Changing Aid-Media Field', p. 863.

79 United Nations Population Fund, Reporting on Gender-Based Violence in the Syria Crisis.

80 R. Sweis, 'In Jordan, Ever Younger Syrian Brides', New York Times (13 September 2014), http: // nyti.ms/XmbDE1. Accessed 8 March 2016.

81 Van Ginneken, Understanding Global News.

82 Altheide, Terror Post $9 / 11$ and the Media.

83 Abbot, 'Working Together'.

84 L. Tsui, 'Saving Us from Noise that Kills: NGOs as News Coordinators in a Networked Public Sphere', NiemanLab (7 December 2009), http://bit.ly/1GPDb9x. Accessed 26 February 2016.

85 M. Montgomery, An Introduction to Language and Society (Oxon: Routledge, 2008). 


\section{References}

Abbot, K., 'Working Together, NGOs and Journalists Can Create Stronger International Reporting', NiemanLab (9 November 2009), http://bit.ly/1J7MVt2. Accessed 20 July 2016.

Al-Khatib, B. and K. Lenner, Alternative Voices on the Syrian Refugee Crisis in Jordan: An Interview Collection (Rosa Luxemburg Stiftung Regional Office Palestine, 2015).

Altheide, P., Terror Post $9 / 11$ and the Media (New York: Peter Lang, 2009).

Alvarado, A., 'Syrian Teen is Called the Malala of Za'atari', CNN International (18 April 2014), http://cnn.it/RrgrWv. Accessed 5 June 2016.

Anderson, M., 'Child Marriage Soars among Syrian Refugees in Jordan', Guardian (16 July 2014), http://bit.ly/1rhUng1. Accessed 12 June 2016.

Aslam, R., 'Peace Journalism: A Paradigm Shift in Traditional Media Approach', Pacific Journalism Review, 17:1 (May 2011), pp. 119-39, https://pjreview.aut.ac.nz/articles/peace-journalismparadigm-shift-traditional-media-approach-476. Accessed 1 May 2016.

Bazzi, S., Arab News and Conflict: A Multidisciplinary Discourse Study (Amsterdam and Philadelphia: John Benjamins Publishing Company, 2009).

BBC, 'Syria Conflict: "Biggest humanitarian crisis since 1945" - Gordon Brown' (4 February 2016), www.bbc.com/news/world-middle-east-35489063. Accessed 7 June 2016.

Bowen, J., The Arab Uprisings: The People Want the Fall of the Regime (London: Simon \& Schuster, 2012).

Bulos, N., 'Jordan Feeling the Strain of Syrian Refugee Crisis', Los Angeles Times (22 March 2013), http://lat.ms/2hftvid. Accessed 18 June 2016.

Connor, T., 'Inside a Refugee Camp with Syria’s “Lost Generation”, NBC News (26 August 2013), http://nbcnews.to/2hdLAN5. Accessed 2 March 2016.

Cooper, G., 'When Lines between NGO and News Organization Blur', NiemanLab (21 December 2009), http://bit.ly/1DpvRKL. Accessed 11 December 2015.

Cottle, S. and D. Nolan, 'Global Humanitarianism and the Changing Aid-Media Field', Journalism Studies, 8:6 (2007), pp. 862-78.

Cottle, S. and D. Nolan, 'How the Media's Codes and Rules Influence the Ways NGOs Work', NiemanLab (16 November 2009), http://bit/ly/1FzwEsR. Accessed 3 March 2016.

Curran, J., Media and Power (London and New York: Routledge, 2002).

Elgot, J., 'The Secret Gardens of Syria’s Refugee Camps', Huffington Post (29 October 2014), http:// huff.to/1toj7Vj. Accessed 25 May 2016.

Fenton, N., 'Has the Internet Changed How NGOs Work with Established Media? Not Enough', NiemanLab (23 November 2009), http://bit.ly/10CCrMB. Accessed 25 May 2016.

Franks, S., Reporting Disasters: Famine, Aid, Politics and the Media (London: Hurst, 2013).

Freedom House, 'Jordan' (2014), https://freedomhouse.org/report/freedom-press/2014/jordan. Accessed 25 May 2016.

Fricker, T., 'Students Promote Learning in Za'atari Camp, Jordan', UNICEF (12 September 2013), www.unicef.org/infobycountry/jordan_70365.html. Accessed 25 May 2016.

Galtung, J. and M. H. Ruge, 'The Structure of Foreign News', Journal of Peace Research, 2:1 (1965), pp. 64-91.

Girl Summit, Girl Summit (2014), www.girlsummit2014.org/Commitment/Show. Accessed 25 May 2016.

Halaby, J., 'Desperate, Some Fleeing Syria Turn to Prostitution', Associated Press (8 March 2013), http://yhoo.it/2bvizct. Accessed 25 May 2016.

Healy, S. and S. Tiller, 'A Review of the Humanitarian Response to the Syrian Refugee Crisis in Jordan 2012-13', MSF (October 2013), www.msf.org.uk/sites/uk/files/jordan_case_study_ final_external_o.pdf. Accessed 25 May 2016. 
James, R., '21 Powerful Images of Forced Marriage Drawn by Syrian Refugees in Jordan', Buzzfeed (17 July 2014), www.buzzfeed.com/richardhjames/powerful-images-of-forced-marriagedrawn-by-syrian-ref\#.okzMzwo7K. Accessed 25 May 2016.

Keane, F., 'Syria: The Boys Who Helped Spark a Revolution', BBC (13 April 2013), http://bbc.in/ 2bGPPwq. Accessed 25 May 2016.

Kirkpatrick, D., 'Syrian Children Offer a Glimpse of a Future of Reprisals', New York Times (3 September 2012), http://nyti.ms/2h8HBBg. Accessed 2 April 2016.

Luck, T., 'In a Jordan Camp, Outsiders Seek Syrian Brides', Washington Post (23 November 2012), http://wapo.st/2bW5bk8. Accessed 21 August 2016.

Lynch, J. and J. Galtung, Reporting Conflict: New Directions in Peace Journalism (Brisbane: University of Queensland Press, 2010).

Lynch, J. and A. McGoldrick, Peace Journalism (Stroud: Hawthorn Press, 2005).

MacKinnon, M., 'Why Young Syrian Refugees will Haunt the Mideast for Decades to Come', The Globe and Mail (14 September 2013), http://bit.ly/1k8a5Z2. Accessed 13 May 2016.

Montgomery, M., An Introduction to Language and Society (Oxon: Routledge, 2008).

Nicolai, S. and S. Hine, 'Investment for Education in Emergencies: A Review of Evidence', Overseas Development Institute (February 2015), http://bit.ly/2bsBRg2. Accessed 2 April 2016.

No Lost Generation (2016), http://nolostgeneration.org/partners. Accessed 18 June 2016.

Oddone, E., 'Azraq Refugee Camp Officially Opened', The Jordan Times (30 April 2014), http:// bit.ly/28T4a6F. Accessed 10 May 2016.

Parker, S., Interview with the author, 29 June 2016.

Philp, C., 'Children are Groomed for War in Huge Refugee Camp', The Times (30 December 2013), www.thetimes.co.uk/article/children-are-groomed-for-war-in-huge-refugee-campcn29tjm97z5. Accessed 10 May 2016.

Polman, L., War Games: The Story of Aid and War in Modern Times (London: Penguin, 2010).

'Post-Truth Politics: Art of the Lie,' Economist (10 September 2016), http://econ.st/2bVXLHU. Accessed 20 October 2016.

Rudoren, J., 'Calm Boss Overseeing a Refugee Camp’s Chaos', New York Times (24 May 2013), http:nyti.ms/2btYNNV. Accessed 26 February 2016.

Save the Children, 'Too Young to Wed: The Growing Problem of Child Marriage among Syrian Girls in Jordan', Save the Children (2014), http:// bit.ly/1FXQIX 3 . Accessed 12 January 2016.

Seaton, J., Carnage and the Media: The Making and Breaking of News About Violence (London: Penguin, 2005).

Sherlock, R. and C. Malouf, 'Syrian Girls "Sold” into Forced Marriages', Daily Telegraph (23 January 2013), http://bit.ly/18XBpDT. Accessed 12 March 2016.

Simpson, J., We Chose to Speak of War and Strife: The World of the Foreign Correspondent (London: Bloomsbury, 2016).

Stokes, J., How to do Media and Cultural Studies: Analysing Media and Cultural Texts (London, Thousand Oaks and New Dehli: Sage, 2003).

Sweis, R., 'In Jordan, Ever Younger Syrian Brides', New York Times (13 September 2014), http:// nyti.ms/XmbDE1. Accessed 8 March 2016.

Taha, K., 'Early, Forced Marriages Haunt Jordan's Syrian Refugees', AFP (12 June 2013), http:/ /bit. ly/2gRRcte. Accessed 13 March 2016.

‘Through Teenagers' Eyes: Unique Snapshots of Syrian Refugee Life', BBC (13 November 2014), www.bbc.co.uk/news/world-middle-east-29724306. Accessed 22 May 2016.

Tsui, L., 'Saving Us from Noise that Kills: NGOs as News Coordinators in a Networked Public Sphere', NiemanLab (7 December 2009), http://bit.ly/1GPDb9x. Accessed 26 February 2016. 
UNICEF, Syria Crisis: Education Interrupted: Global Action to Rescue the Schooling of a Generation (UNICEF MENA, 2013), http://uni.cf/2iAQ47. Accessed 22 May 2016.

UNICEF, Shattered Lives: Challenges and Priorities for Syrian Children and Women in Jordan (Jordan: UNICEF, 2013), www.unicef.org/mena/MENA-Shattered_Lives_June11.pdf. Accessed 9 May 2016.

UNICEF, A Study on Early Marriage in Jordan 2014 (Jordan: UNICEF, 2014), www.unicef.org/ mena/UNICEFJordan_EarlyMarriageStudy2014(1).pdf. Accessed 25 May 2016.

United Nations Population Fund, Reporting on Gender-Based Violence in the Syria Crisis: A Journalists Handbook (UNFPA, 2014), www.unfpa.org/sites/default/files/resource-pdf/ UNFPA\%20Journalsits\%275\%20Handbook\%20Small\%5B6\%5D.pdf. Accessed 25 May 2016.

Van Ginneken, J., Understanding Global News: A Critical Introduction (London, Thousand Oaks and New Delhi: Sage, 1996).

Vingiano, A., 'Syrian Children Master Taekwondo at the Za'atari Refugee Camp', Buzzfeed ( 2 July 2014), http://bzfd.it/2glblHi. Accessed 13 June 2016.

Voluntary Services Overseas, The Live Aid Legacy: The Developing World through British Eyes A Research Report (London: VSO, 2001).

Waisboard, S., 'Can NGOs Change the News?' International Journal of Communication, 5 (2011), pp. 142-65, http://ijoc.org/index.php/ijoc/article/view/787/515. Accessed 11 April 2016.

Wilkes, S., 'Jordan Opens New Camp for Syrian Refugees Amid Funding Gaps', UNHCR (30 July 2012), http://bit.ly/2b7nnqT. Accessed 21 May 2016. 